\title{
Serum Resistin Levels in Prediabetic Individuals
}

\section{Prediyabetik Bireylerin Serum Rezistin Seviyeleri}

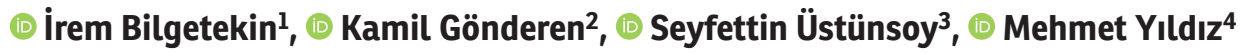 \\ ${ }^{1}$ Gazi University Faculty of Medicine, Department of Medical Oncology, Ankara, Turkey \\ ${ }^{2}$ Dumlupınar University Evliya Celebi Training and Research Hospital, Clinic of Intensive Care Unit, Kütahya, Turkey \\ ${ }^{3}$ Special Esencan Hospital, Clinic of Medical Biochemistry, İstanbul, Turkey \\ ${ }^{4}$ Dıșkapı Yıldırım Beyazıt Training and Research Hospital, Clinic of Internal Medicine, Ankara, Turkey
}

\begin{abstract}
Objective: In this study we aimed to investigate the relationship between insulin resistance and pre-diabetic patients' serum resistin levels, inflammatory and oxidative stress parameters that take part in the progress of type 2 diabetes mellitus (DM). Resistin is a newly discovered adipokine which is secreted from adipose tissue that has important roles in the pathogenesis of obesity mediated-insulin resistance.

Methods: 59 adult patients who applied to the internal medicine out patient clinic were enrolled to the study [41 IFG (impaired fasting glucose), 18 IFG+IGT (impaired fasting glucose+impaired gluose tolerance)]. Routine biochemical and haematological parameters were calculated by autoanalyzers. Serum resistin levels were measured by ELISA procedure. Statistical analyses were performed by SPSS for Windows.

Results: Resistin levels in IFG and IFG+IGT groups were significantly higher compared to control group. A positive correlation were detected between serum resistin levels and age, FPG, HbAIC, Homa-IR, oral glucose tolerance test (OGTT) 0. hour, OGTT 2. hour also, there were a negative correlation between serum resistin levels and high-density lipoprotein.
\end{abstract}

Conclusion: The onset or progression of diabetes could be slowed down by interveining the metabolic and modifiable parameters in prediabetic patients who have high risk of developing diabetes.

Keywords: Impaired fasting glucose, impaired glucose tolerance, resistin

ÖZ

Amaç: Biz bu çalıșmamızda tip 2 diabetes mellitus (DM) gelișiminde rol aldığı öne sürülen nflamasyon, oksidatif stres ve insülin direncini gösteren parametrelerin prediyabetik dönemdeki düzeylerinin, serum rezistin düzeyi ile olan ilişkisini araştırmayı amaçladık.

Yöntemler: Rezistin; son yıllarda keșfedilmiş, yağ dokusundan salgılanan adipokindir. Son dönemde yapılan çalıșmalar obeziteyle ilișkili insulin direncinde önemli rolünün olduğunu göstermiștir. Çalıșmamıza Ankara Dıșkapı Yııdıım Beyazıt Eğitim ve Araștırma Hastanesi Dahiliye polikliniklerine Temmuz 2012 ve Ekim 2012 tarihleri arasında genel muayene için bașvuran, çalıșma kriterlerine uyan 59 prediyabetik (4l BAG ve 18 BAG+BGT'li) hasta dahil edilmiștir. Laboratuvar ölçümleri oto analizörlerde, serum rezistin düzeyleri ise ELISA kiti ile ölçülmüștür. Istatistiksel analizler SPSS programında yapılmıştır.

Bulgular: Prediyabetik hasta gruplarında serum rezistin düzeyi kontrol grubuna göre anlamlı yüksek bulunmuştur. Çalışmamızda yaș, AKŞ, HbAlc, Homa-IR, oral glikoz tolerans testi (OGGT) 0. saat ve OGGT 2. saat ile rezistin arasında istatistiksel olarak anlamlı pozitif korelasyon görülürken, yüksek yoğunluklu lipoprotein ile rezistin arasında istatistiksel olarak anlamlı negatif korelasyon bulunmuştur

Sonuç: Bu çalışma DM gelișme riski yüksek olan prediyabetik hastalarda metabolik parametrelerin ortaya çıkarılmasının ve değiştirilebilir parametrelere müdahale edilmesinin, diyabete ilerleyişin yavașlatılmasını sağlayabileceğini serum rezistin seviyeleri değerlendirilerek ortaya koymuștur.

Anahtar kelimeler: Bozulmuş açlık glikozu, bozulmuş glikoz toleransı, rezistin

Received/Geliș tarihi: 26.02.2018 | Accepted/Kabul tarihi: 05.08.2018

Address for Correspondence/Yazıșma Adresi: Seyfettin Üstünsoy, Special Esencan Hospital, Clinic of Medical Biochemistry, İstanbul, Turkey Phone/Telefon: 2124445058 E-mail/E-posta: seyfettinustunsoy@gmail.com ORCID-ID: orcid.org/0000-0002-0985-8121 


\section{INTRODUCTION}

Type 2 diabetes mellitus (DM) is a major cause of morbidity and mortality all over the world due to its microvascular and macrovascular complications. Genetic and environmental factors claimed to be taking role in the pathogenesis of diabetes, however previous studies revealed that enflammation, oxidative stress and insulin resistance are the key steps taking part in the development of diabetes. Resistin is a newly discovered peripheral signaling adipokine which is secreted from adipose tissue. In vivo and in vitro studies have shown that resistin administration causes insulin resistance. It is claimed to be an obesity and type 2 diabetes related hormone (1). This adipokine exists in the serum of mammals at measurable levels. It is assumed as a major regulatory molecule of body fat mass distribution, through peripheral signalling negative feedback mechanism (2). Resistin disrupts the glucose tolerance by preventing the effect of insulin at cellular levels, reduces glucose uptake and insulin sensitivity, leads to insulin resistance. Resistin behaves as proinflammatory cytokines, whether associated with insulin resistance or not, it is shown to be involved in inflammatory disorders such as subclinical inflammation, atherosclerosis, cardiovascular diseases, non-alcoholic fatty liver disease, rheumatic diseases, malignant tumors, inflammatory bowel disease and chronic kidney diseases. Also, resistin modulates several molecular pathways in metabolic, inflammatory and autoimmune diseases. Moreover, resistin establishes a connection between the enflammation and metabolic symptoms which differs it from other adipokines. Several studies performed on serum inflammatory markers, in patients with DM, has revealed the strong relationship between DM and coronary artery diseases. In a smilar vein, there are many on-going studies investigating the association between the resistin and cardiovascular diseases, DM, metabolic syndrome, hypothyroidism.

In this study, we aimed to investigate the association between serum resistin levels and enflammation markers, oxidative stress parameters and insulin resistance in prediabetic period called IFG (impaired fasting glucose) and IGT (impaired glucose tolerance) which are considered taking role in the development of type $2 \mathrm{DM}$. Moreover, IFG and IGT patients' risk of developing DM is very high compared to the normal serum glucose population. Thus discovery of metabolic parameters causing this condition may help to slow down or eliminate the progression to diabetes by intervening the modifiable parameters in this stage patient population.

\section{METHODS}

In this study, we have included in 88 voluntary participants admitted to internal medicine outpatient clinic of Ankara Dışkapı Yıldırım Beyazıt Training and Research Hospital between July to October 2012. The study population were composed of 59 prediabetic (4I IFG and 18 IFG + IGT 's patients) patients and 29 healthy (control group) subjects. People newly diagnosed as prediabetic, without a history of comorbid disease, were enrolled to the study. The patients who were diagnosed before with a disease effecting serum resistin levels like type 1/2 DM, hypertension, hyperlipidemia, history of ischemic heart disease and obesity [BMI (body mass index) $>30$ ] were not included in the study. Also, we have excluded the patients, if there is a possibility that might change oral glucose tolerance test (OGTT), serum ferritin, high sensitive $\mathrm{C}$-reactive protein and other laboratory test results: hemoglobin levels below 12 $\mathrm{mg} / \mathrm{dL}$, acute and chronic infections, chronic diseases, acute coronary syndromes, autoimmune diseases, endocrine diseases, inflammatory diseases, cancer and also regular drug usage: oral contraceptive, glucocorticoids, diuretics, thyroxine, beta-blockers.

Patients' medical history was taken and physical examination was performed. At least after 15 minutes of resting, in a sitting position, in a quiet room blood pressure were measured by sphygomanometer. Venous blood samples of patients were taken after 12-14 hours fasting by venopuncture. Resistin were studied from samples by using human ELISA [kits (AssayMax Human Resistin ELISA Kit)] [sensivity: (minimum detectable level of Resistin) = 0.2ng/mL, intra-assay CV: 4.2 and inter-assay CV:7.3\%]

Fasting blood glucose, lipid parameters, iron/total iron binding capacity, gamma-glutamyl transferase and uric acid were studied by Roche P800 Modular Analyzer Clinical Chemistry instrument or Olympus AU 5200 Analyzer. These markers were studied to exclude enflammation and the other chronic diseases such as anemia, and hyperlipidemia. Low density lipoprotein (LDL) cholesterol was calculated using the Friedewald formula: LDL=Total cholesterol[HDL(high density lipoprotein)+TG (triglyceride)/5]. TSH (thyroid stimulating hormone), FT3 (free triiodothyronine) and FT4 (free tetraiodotyronine) were studied by immulite 2000 direct primary care analyzer. Complete blood count 
were studied with Automated Hematology Analyzer Sysmex SE 9000. Dışkapı Yıldırım Betazit EAH. 27.02.2012, 01/13.

\section{Measurement of Serum Resistin Levels}

Frozen plasma samples thawed at room temperature and then serum resistin levels were measured by a commercially avaliable ELISA kit (assaymax Human Resistin ELISA Kit) produced for humans. The sensitivity (minimum detectable level of Resistin) of the assay was $0.2 \mathrm{ng} / \mathrm{mL}$. The interassay and the intra-assay reproducibility of kit's coefficients of variation were $7.3 \%$ and $<4.2 \%$, respectively.

\section{Statistical Analysis}

This is a case-control study which was evaluated the serum resistin levels of IFG and IGT patients, and compared the aquired data with the literature. Data analysis was performed by using SPSS for Windows 11.5 package program. The distribution of continuous measuring variables whether disperses close to normal determined with the Shapiro-Wilk test and homogenity of variance were examined with the Levene test. Descriptive statistics for continuous variables expressed as mean \pm standard deviation or median (interquartile width) and the nominal variables was shown in the form of percentage (\%) or the number of cases (\#). The average difference significance between the groups were determined by One-Way Analysis of Variance (One-Way ANOVA) and the significance of the difference in terms of median values were examined by Kruskal-Wallis test. At the end of the One-Way ANOVA or Kruskal-Wallis test if there is a significant difference in the results to identify the cause post hoc Conover or Tukey's multiple comparison test was used. Nominal variables were evaluated using Pearson's chi-square test. $\mathrm{P}<0.05$ was considered statistically significant for the results.

\section{RESULTS}

We have enrolled 59 prediabetic (4I IFG and 18 IFG + IGT'li) patients to the study, according to the inclusion and exclusion criterias of our study, who apllied to Ankara Dışkapı Yıldırım Beyazıt Training and Research Hospital, internal medicine outpatient clinic for the general examination between July 2012 and October 2012. The study population were consisted of 21 men and 38 women in prediabetic group and healthy volunteers consisted of 13 men and 16 women in control group.

We investigated the relationship between the serum resisitin levels and some other parameters. According to result of analysis age, fasting blood glucose, HbAlc, HomeIR (homeostasis model assesment-insulin resistance), OGGT 0. and OGGT 2. hours and serum resistin levels correlated statistically significantly and correlation was in the same way, on controrary a statistically significant inverse correlation was found between $\mathrm{HDL}$ and serum resistin levels $(p<0.05)$.

In terms of blood pressure, cholesterol, $\mathrm{HDL}, \mathrm{LDL}$, creatinine, TSH, FT3, FT4, ferritin, GGT, Fibrinogen, hemoglobin, white blood cell and mean platelet volume values there was not a statistically significant differences between the groups.

The figure l. shows the mean serum resistin levels of study groups. As the end of assay the resistin concentration of groups calculated as $4 \mathrm{ng} / \mathrm{mL}, 3.9 \mathrm{ng} / \mathrm{mL}$ and $2.6 \mathrm{ng} / \mathrm{mL}$

Table 1: Demographic data and variables of study population

\begin{tabular}{|c|c|c|c|c|}
\hline & Control $(n=29)$ & IFG $(n=41)$ & IFG+IGT (n=18) & $\mathbf{p}$ \\
\hline Age (year) & $32.3 \pm 6.8 \mathrm{a}, \mathrm{b}$ & $44.4 \pm 9.8 \mathrm{a}$ & $47.0 \pm 9.0 \mathrm{~b}$ & $<0.001$ \\
\hline Sex & & & & 0.227 \\
\hline Male & $13(44.8 \%)$ & $12(29.3 \%)$ & $9(50.0 \%)$ & \\
\hline Female & $16(55.2 \%)$ & $29(70.7 \%)$ & $9(50.0 \%)$ & \\
\hline Menapause & $1(6.3 \%)$ & $10(34.5 \%)$ & $1(11.1 \%)$ & 0.063 \\
\hline Smoking History & $9(31.0 \%)$ & $9(22.0 \%)$ & $5(27.8 \%)$ & 0.685 \\
\hline Family History (DM) & $16(55.2 \%)$ & $26(63.4 \%)$ & $13(72.2 \%)$ & 0.495 \\
\hline Exercise & $5(17.2 \%)$ & $11(26.8 \%)$ & $3(16.7 \%)$ & 0.536 \\
\hline Body mass index $\left(\mathrm{kg} / \mathrm{m}^{2}\right)$ & $23.5 \pm 3.3 a, b$ & $26.7 \pm 2.2 \mathrm{a}$ & $27.3 \pm 2.1 b$ & $<0.001$ \\
\hline Waist circumference $(\mathrm{cm})$ & $82.6 \pm 12.7 a, b$ & $90.9 \pm 9.9 a$ & $94.2 \pm 7.6 b$ & $<0.001$ \\
\hline \multicolumn{5}{|c|}{ a: Control vs IFG group ( $p<0.001)$, b: Control vs IFG+IGT $(p<0.01)$, c: IFG vs IFG+IGT $(p=0.021)$} \\
\hline IFG: Impaired fasting glucose IC & se tolerance, DM: D & & & \\
\hline
\end{tabular}


in IFG, IFG + IGT and control group, respectively. While the IFG and IFG + IGT compared to control group, serum resistin levels were significantly higher in IFG and IFG + IGT group patients $(p<0.001)$. Nevertheless, serum resistin levels of IFG+IGT and IFG were similar and there was not a statistically significant difference between patients.
IFG and IFG+IGT patients' HOMA-IR were significantly higher than the control group ( $p<0.001$ ) (Figure 2).

IFG and IFG + IGT patients' serum C-reactive protein (CRP) levels were significantly higher than the control group ( $p=0.017$ ) (Figure 3 ).

Table 2: Laboratory results and variables of study population

\begin{tabular}{|c|c|c|c|c|}
\hline & Control $(n=29)$ & IFG $(n=41)$ & IFG+IGT (n=18) & $\mathbf{p}$ \\
\hline Fasting blood glucose & $81.0(15.0) a, b$ & $108.0(6.0) \mathrm{a}$ & $113.0(16.5) \mathrm{b}$ & $<0.001$ \\
\hline Cholesterol & $179.8 \pm 41.6$ & $192.1 \pm 38.5$ & $208.4 \pm 31.8$ & 0.050 \\
\hline HDL & $43.0(18.0)$ & $45.0(16.5)$ & $45.0(18.5)$ & 0.745 \\
\hline LDL & $111.6 \pm 35.3$ & $116.8 \pm 30.3$ & $121.4 \pm 19.6$ & 0.547 \\
\hline Triglicerides & $82.0(65.5) a, b$ & $127.0(86.5) \mathrm{a}$ & $136.0(139.7) \mathrm{b}$ & 0.008 \\
\hline Urea & $22.9(6.8) b$ & $25.0(9.8) \mathrm{c}$ & 29.0 (9.5) b, c & 0.015 \\
\hline CRP & $1.0(1.7) \mathrm{b}$ & $1.5(3.2)$ & $3.8(6.4) \mathrm{b}$ & 0.017 \\
\hline Insulin & $6.1(5.2) \mathrm{a}, \mathrm{b}$ & $11.5(6.1) \mathrm{a}$ & $11.1(14.5) \mathrm{b}$ & $<0.001$ \\
\hline Uric acid & $4.6(2.3) \mathrm{b}$ & $5.0(2.1) \mathrm{c}$ & 5.7 (2.3) b, c & 0.029 \\
\hline Sedim & $11.0(9.0) \mathrm{a}, \mathrm{b}$ & $16.0(9.0) \mathrm{a}$ & $17.0(11.2) \mathrm{b}$ & 0.004 \\
\hline HbAlc & $5.4(0.3) a, b$ & $5.5(0.5) \mathrm{a}, \mathrm{c}$ & $6.2(0.7) b, c$ & $<0.001$ \\
\hline Homa-IR & $1.2(0.9) \mathrm{a}, \mathrm{b}$ & $3.0(1.6) \mathrm{a}$ & $3.3(3.6) \mathrm{b}$ & $<0.001$ \\
\hline OGTT 0 & $81.0(15.0) \mathrm{a}, \mathrm{b}$ & $107.0(5.0) \mathrm{a}_{1} \mathrm{c}$ & 114.5 (13.0) b, c & $<0.001$ \\
\hline OGTT 2 & $100.0(17.5) \mathrm{a}, \mathrm{b}$ & $112.0(32.5) \mathrm{a}, \mathrm{c}$ & $168.5(20.0)$ b, c & $<0.001$ \\
\hline Resistin & $2.6(0.9) a, b$ & $4.0(2.7) \mathrm{a}$ & $3.9(2.4) b$ & $<0.001$ \\
\hline MPV & $9.2(1.8)$ & 8.9 (1.8) & 8.3(1.3) & 0.094 \\
\hline
\end{tabular}

a: Control vs IFG group ( $p<0,001)$, b: Control vs IFG+IGT ( $p<0,01)$, c: IFG vs IFG+IGT $(p=0,021)$

IFG: Impaired fasting glucose, CRP: C-reactive protein, OGTT: Oral glucose tolerance test MPV: Mean platelet volüme, HDL: High density lipoprotein

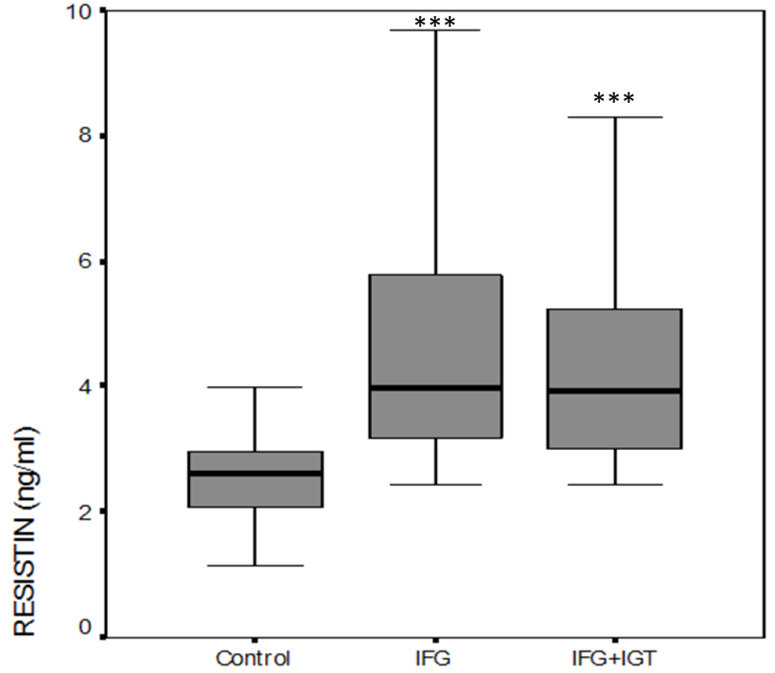

Figure 1: Serum resistin levels of study groups

**:* Control vs impaired fasting glucose group and IFG+IGT $(p<0.001)$

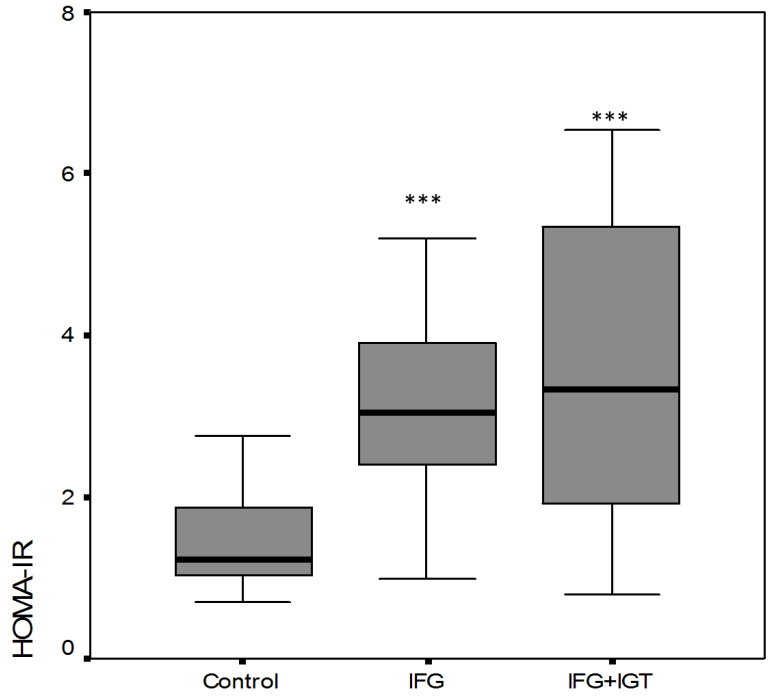

Figure 2: Serum HOMA-IR levels of study groups **: Control vs impaired fasting glucose group and IFG+IGT $(p<0.001)$ 


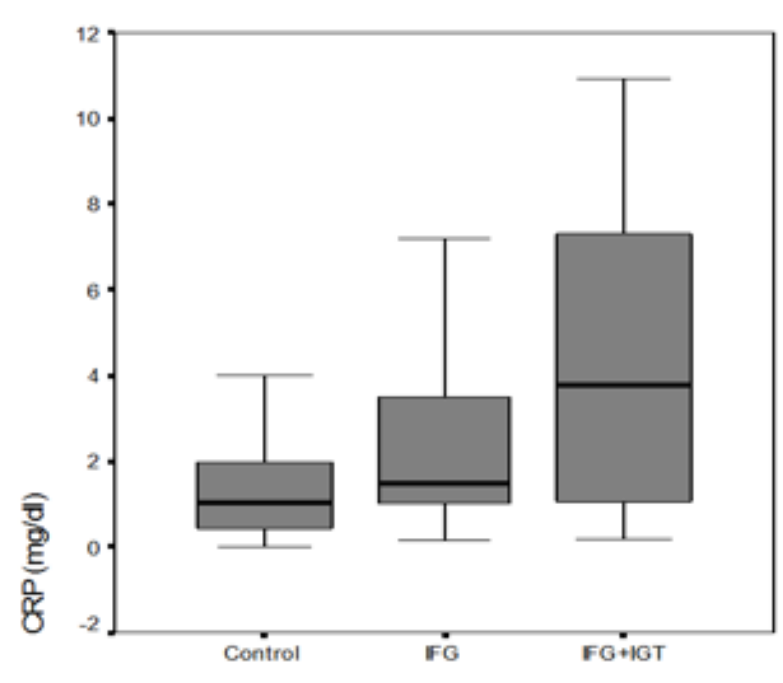

Figure 3: Serum C-reactive protein levels of study groups **:* Control vs IFG group and IFG+IGT $(p<0.001)$

\section{DISCUSSION}

Resistin is a new adipocytokine discovered in recent years. It is believed to be a novel polypeptide molecule taking role in peripheral signalling. It is secreted from adipocytes where it is abundantly found. Also has a relationship with obesity and type 2 diabetes (1-4). Resistin exists in the serum of mammals at measurable levels and may be regulating body fat mass by negative feedback through peripheral signaling (1). Reilly et al. have published a paper which has demonstrated that plasma resistin levels have been associated with metabolic and inflammatory markers. Resistin levels were significantly correlated with coronary artery calcification. According to results resistin can be an independent marker of atherosclerosis in humans (5). Some of the studies about resistin have shown that resistin contribute to the cardiovascular pathologies by stimulating endothelin- 1 , vascular cell adhesion molecule- 1 and monocyte chemoatractant protein-1 (6). Muredach et al. have also found a significant correlation between resistin levels and inflammatory markers and atherosclerosis of coronary arteries (7). According to the study results serum resistin levels was seen as decisive marker in patients with metabolic syndrome and coronary atherosclerosis.

In our study we compared resistin levels between prediabetic patients and the control group and evaluated the relationship between resistin levels and some other parameters. Impaired fasting glucose and impaired glucose tolerance is considered as prediabetic period are the two
Table 3: Correlation Coefficients with p values between Resistin and Anthropometric/Laboratory Measurements

\begin{tabular}{|c|c|c|}
\hline Variables & $\begin{array}{l}\text { Correlation } \\
\text { Coefficients }\end{array}$ & $\mathbf{p}$ \\
\hline Age & 0.368 & $<0.001$ \\
\hline Height & 0.019 & 0.858 \\
\hline Weight & 0.116 & 0.280 \\
\hline BMI & 0.183 & 0.088 \\
\hline Waist Circumference & 0.172 & 0.109 \\
\hline Blood Pressure & -0.059 & 0.588 \\
\hline FBG $* \cdots$ & 0.488 & $<0.001$ \\
\hline Cholesterol & 0.016 & 0.880 \\
\hline HDL & -0.221 & 0.038 \\
\hline LDL & 0.03 & 0.978 \\
\hline Creatinin & 0.039 & 0.718 \\
\hline TSH & 0.017 & 0.876 \\
\hline fT3 & -0.046 & 0.668 \\
\hline fT4 & 0.002 & 0.986 \\
\hline CRP & 0.207 & 0.053 \\
\hline Ferritin & 0.147 & 0.172 \\
\hline Insuine & 0.125 & 0.247 \\
\hline GGT & 0.034 & 0.754 \\
\hline Uric Acid & -0.055 & 0.609 \\
\hline Fibrinogen & 0.132 & 0.219 \\
\hline Hbg & -0.014 & 0.897 \\
\hline WBC & 0.132 & 0.220 \\
\hline MPV & -0.152 & 0.158 \\
\hline ESR & 0.094 & 0.382 \\
\hline HbAlC & 0.312 & 0.003 \\
\hline HOMA-IR & 0.239 & 0.025 \\
\hline OGGTO & 0.476 & $<0.001$ \\
\hline OGTT2 & 0.348 & $<0.001$ \\
\hline \multicolumn{3}{|c|}{ 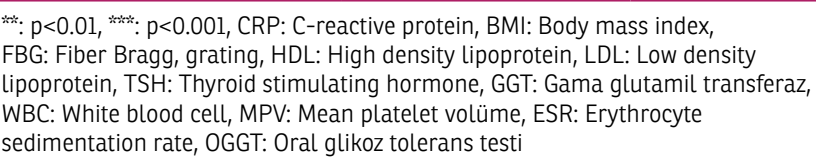 } \\
\hline
\end{tabular}

cases associated with the beggining of insulin resistance occurs with hyperglycemia. In our study, prediabetic (IFG+IGT and IFG patients) and healthy control groups were compared in terms of resistin values and difference was found to be statistically significant as being higher in prediabetic patients $(p<0.001)$. There was no statistically significant differences between IFG and IFG+IGT group patients in terms of serum resistin levels. There are 
conflicting human study publications in the literature about the circulating resistin levels and the relationship between obesity and type 2 diabetes. A number of studies has reported that resistin exists at very low levels on human adipose tissue and also there is not a meaningful difference in resistin expression of humans whether they are lean, obese, insulin resistant or insulin sensitive type 2 diabetic. Moreover, resistin is not a hormone related to obesity and diabetes (8-10). On the contrary of the above publications, different studies have demonstrated that type 2 diabetic patients resistin levels are higher than the controls, cytokines generated by adipose tissue such as TNF-alpha (tumor necrosis factor-alpha) and interleukin-6 (IL-6) are responsible for increased enflammation. Thus, these incereased proinflammatory cytokines stimulate resistin and CRP production, also contribute to the development of low level chronic enflammation and insulin resistance in obese patients. Moreover, insulin resistance and resistin is reported to have a positive correlation between each other (10-12). In our study, a weak but positive correlation between resistin and CRP levels are seen nevertheless correlation was not statistically significant. Joanna Janowska et al. (13) analysed the relationship between the proinflammatory cytokines and serum resistin levels in obese women with normal glucose tolerance and impaired glucose tolerance. At the end of the study, a significant correlation between serum resistin levels and IL-6 levels and body fat mass was observed in patients with impaired glucose tolerance. Body mass index (BMI), HOMA-IR, fasting plasma glucose and fasting plasma insulin levels were not correlated with serum resistin levels. In addition, LDL cholesterol levels were negatively correlated with resistin levels (13). Lee $\mathrm{JH}$. (9) have studied plasma resistin levels in patients with obesity and atherogenic lipid profile. In conclusion, they have not detected a significant correlation between serum resistin levels and insulin resistance and dyslipidemia. In our study, although a positive correlation between LDL levels and resistin were observed, that was not statistically significant $(p=0.978)$. However, statistically significant inverse correlation was found between HDL and serum resistin levels ( $p=0.038$ ). Degawa-Yamauchi et al. (14) have identified a positive correlation between serum resistin levels and BMI but they have not reported a significant relationship between insulin resistance and serum resistin levels in their study. Resistin is produced and released from bone marrow and peripheral mononuclear blood cells in large quantities in human beings. Besides, it is also expressed by some more organs such as lung, pancreas and plasenta (15-17). In clinical humans studies resistin levels were identified associated with atherosclerotic risk factors and inflammatory markers independently of BMI. Similarly, resistin is inducible by endotoxins and cytokines. Moreover, previous studies have shown the link between the inflammatory markers and the resistin levels in diabetic patients and even resistin said to be a decisive marker for cardiovascular disease (5). In our study, we have selected the cases whose BMI are below 30 (BMI was found in the IFG group as $26.7 \pm 2.2$ and in the IFG+IGT group as $27.3 \pm 2,1)$ and found a statistically significant positive relationship between serum resistin and BMI ( $p=0.088)$. Azuma et al. (18) have found a significant correlation between $\mathrm{BMI}$ and serum resistin levels in a study, but the correlation between waist circumference and resistin was not calculated in the study. Also, the same study have shown that serum resistin levels were not correlated significantly with age. In our study, age and resistin are correlated in the same direction statistically significantly $(p<0.001)$. We couldn't find significant correlation between resistin and waist circumference $(p=0.109)$. Silhen et. al (19) detected a significant correlation between BMI and HOMA-IR, nonetheless a significant correlation between $\mathrm{BMI}$ and resistin were not detected in the same study. In our study, a statistically significant positive correlation was found between resistin and HOMA-IR. ( $p=0.025)$. Osawa et al. (20) have compared normal glucose tolerant control group with the Japanese type 2 DM patients and have found serum resistin level higher in type 2 DM. In addition, regression analysis of serum resistin levels has been shown as an independent factor of type 2 DM in this study. Resistin has been previously displayed associated with insulin resistance in animal models (21). Debating results obtained from different human studies, some studies have shown a positive correlation $(22,23)$, others have not $(9,24)$. The primary sources of resistin is considered to be enfiltrating macrophages to the human adipose tissue (25). Circulating resistin correlated with adiposity and that may play a role in pro-inflammatory signaling.

In this study, we have selected the cases whose BMI are below 30. Resistin levels of our study population did not show statistically significant relationship with BMI, whereas HOMA-IR showed a strong positive correlation consistant with previously made studies which stated that type 2 diabetes is associated with chronic enflammation (26) and also main source of circulating resistin is macrophages 
and monocytes rather than the adipose tissue, morover pro-inflammatory agents released from these cells lead to insulin resistance $(8,15)$.

\section{Study Limitations}

Although this research was carefully prepared, we are still aware of its limitations and shortcomings. First of all, the population of the experimental group is small, only 88 patients were included in the study and might not represent the majority of the pre diabetic patients. Therefore, to generalize the results for larger groups, the study should be conducted on larger populations. Second, the control and patient groups were not age mathced due to short dealine, we would do a better work if we have more time. In addition, the control and patient groups were not weight mathced.

\section{CONCLUSION}

In conclusion, serum resistin levels were compared between prediabetic patients and healthy control groups in our study. Serum resistin levels in prediabetic patients were observed significantly higher than the control group $(p<0.001)$. In our study, statistically significant same way correlation was observed between age, fasting blood glucose, HbAlc, HOMA-IR, OGGT 0., OGGT $2^{\text {nd }}$ hours and serum resistin levels, by the way a statistically significant inverse correlation was found between HDL an serum resistin levels. Moreover, in our study existance of increased resistin levels in prediabetic patients compared with controls and strong positive relationship between HOMAIR and resistin levels suggests that increased resistin levels may lead to the development of insulin resistance. Our results strongly support that resistin play an important role in insulin resistance. Therefore, resistin could be a good candidate biomarker for the follow up of prediabetic patients before the evolution of diabetes. Also, the onset and progression to diabetes could be slowed down by interferring the metabolic and modifiable parameters in prediabetic (IFG and IGT) patients with a very high risk of developing diabetes, and resistin could be a target biomolecule that can be used for this purpose.

\section{Ethics}

Ethics Committee Approval: Dışkapı Yıldııım Betazit EAH. 27.02.2012, 01/13

\section{Authorship Contributions}

Surgical and Medical Practices: I.B., K.G., Concept: M.Y., I.B., Design: K.G., İ.B., Data Collection or Processing: I.B., K.G., Analysis or Interpretation: M.Y., S.Ü., Literature Search: I.B., S.Ü., M.Y., Writing: S.Ü., I.B.

Conflict of Interest: No conflict of interest was declared by the authors.

Financial Disclosure: The authors declared that this study received no financial support.

\section{REFERENCES}

1. Steppan CM, Lazar MA. Resistin and obesity-associated insulin resistance. Trends Endocrinology and Metabolism 2002;13:18-23.

2. Wiecek A, Kokot F, Chudek J,Adamczak M. The adipose tissue- a novel endocrine organ of interest to the nephrologist. Nefrol Dial Transplant 2002;17:191-5.

3. Berger A. Resistin: a new hormone that links obesity with type 2 diabetes, BMJ 2001;322:193.

4. Uysal KT, Wiesbrock SM, Marino MW, Hotamısligil GS. Protection from obesity- induced insulin resistance in mice lacking TNF-alpha function. Nature 1997;389:610-4.

5. Reilly MP, Lehrke M, Wolfe ML, Rohatgi A, Lazar MA, Rader DJ. Resistin is an inflammatory marker of atherosclerosis in humans. Circulation 2005;111:932-9.

6. Kawanami D, Maemura K, Takeda N, Harada T, Nojiri T, Imai $Y$, et al. Direct reciprocal effects of resistin and adiponectin on vascular endothelial cells: a new insight into adipocytokine-endothelial cell interactions. Biochem. Biophys Res Commun 2004;314:415-9.

7. Reilly MP, Lerkhe M, Wolfe ML, Rohatgi A, Lazar MA, Rader DJ. Resistin is an inflammatory marker of atherosclerosis in humans. Circulation 2005;111:932-9.

8. Bastard JP, Maachi M, Lagathu C, Kim MJ, Caron M, Vidal H, et al. Recent advances in the relationship between obesity, inflammation, and insulin resistance. Eur Cytokine Netw 2006;17:4-12.

9. Lee $J H$, Chan JL, Yiannakouris $N$, Kontogianni M, Estrada E, Seip $\mathrm{R}$, et al. resistin levels are not associated with obesity or insulin resistance in humans and are not regulated by fasting or leptin administration: cross-sectional and interventional studies in normal, insulin-resistant, and diabetic subjects. J Clin Endocrinol Metab 2003;88:4848-56.

10. Nagaev I, Smith U. Insulin resistance and type 2 diabetes are not related to resistin expression in human fat cells or skeletal muscle. Biochemical Biophysical Research Communications 2001;285:561-4.

11. Hui-bing H, Migita K, Miyashita T, Maeda Y, Nakamura M, Yatsuhashi $\mathrm{H}$, et al. Relationship between serum resistin concentrations and inflammatory markers in patients with type 2 diabetes mellitus. Metabolism 2006;55:1670-3.

12. Mojiminiyi OA, Abdella NA. Associations of resistin with inflammation and insulin resistance in patients with type 2 diabetes mellitus. Scand J Clin Lab Invest 2007;67:215-25. 
13. Janowska J, Zahorska-Markiewicz B, Olszanecka-Glinianowicz M. Relationship between serum resistin concentration and proinflammatory cytokines in obese women with impaired and normal glucose tolerance, Metabolism Clinical and Experimental 2006,55:1495-9.

14. Degawa-Yamauchi $M$, Bovenkerk JE, Juliar BE, Watson $W$, Kerr $K$, Jones $R$, et al. Serum resistin (FIZZ3)protein is increased in obese humans. J Clin Endocrinol Metab 2003;88:5452-5.

15. Patel L, Buckels AC, Kinghorn IJ, Murdock PR, Holbrook JD, Plumpton $C$, et al. Resistin is expressed in human macrophages and directly regulated by PPAR gamma activators. Biochem Biophys Res Commun 2003;300:472-6.

16. Yura S, Saqawa $\mathrm{N}$, Itoh $\mathrm{H}$, Kakui $\mathrm{K}$, Nuamah MA, Korita $\mathrm{D}$, et al. Resistin is expressed in the human placenta. J Clin Endocrinol Metab 2003;88:1394-7.

17. Minn AH, Patterson NB, Pack S, Hoffmann SC, Gavrilova O, Vinson C, et al. Resistin is expressed in pancreatic islets. Biochem Biophys Res Commun 2003;310:641-5.

18. Azuma K, Katsukawa F, Oquchi S, Murata M, Yamazaki H, Shimada A, et al. Correlation between serum resistin level and adiposity in obese individuals. Obesity Research 2003;11:997-1001.

19. Silha JV, Murphy LJ. Serum resistin (FIZZ3) protein is increased in obese humans. J Clin Endocrinol Metab 2004;89:1977-8.

20. Osawa H, Onuma H, Ochi M, Murakami A, Yamauchi J, Takasuka T, et al. Resistin SNP-420 determines its monocyte mRNA and serum levels inducing type 2 diabetes. Biochem Biophys Res Commun 2005;335:596-602.

21. Steppan CM, Bailey ST, Bhat S, Brown EJ, Banerjee RR, Wright $\mathrm{CM}$, et al. The hormone resistin links obesity to diabetes. Nature 2001;409:307-12.

22. Heilbronn LK, Rood J, Janderova L, Albu JB, Kelley DE, Ravussin E, et al. Relationship between serum resistin concentrations and insulin resistance in nonobese, obese, and obese diabetic subjects. J Clin Endocrinol Metab 2004;89:1844-8.

23. Osawa H, Tabara $Y$, Kawamoto R, Ohashi J, Ochi M, Onuma $H$, et al. Plasma resistin, associated with single nucleotide polymorphism -420 , is correlated with insulin resistance, lower HDL cholesterol, and high-sensitivity $\mathrm{C}$-reactive protein in the Japanese general population. Diabetes Care 2007;30:1501-6.

24. Vozarova de Courten B, Degawa-Yamauchi M, Considine RV, Tataranni PA. High serum resistin is associated with an increase in adiposity but not a worsening of insulin resistance in Pima Indians. Diabetes 2004;53:1279-84.

25. Curat CA, Wegner V, Sengenes C, Miranville A, Tonus C, Busse R, et al. Macrophages in human visceral adipose tissue: increased accumulation in obesity and a source of resistin and visfatin. Diabetologia 2006;49:744-7.

26. Pickup JC. Inflammation and activated innate immunity in the pathogenesis of type 2 diabetes. Diabetes Care 2004;27:813-23. 